ENTREPRENEURSHIP AND SUSTAINABILITY ISSUES

ISSN 2345-0282 (online) http://jssidoi.org/jesi/

2021 Volume 9 Number 2 (December)

http://doi.org/10.9770/jesi.2021.9.2(34)

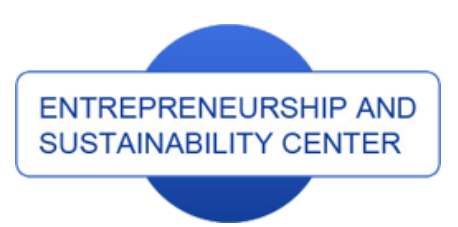

Publisher
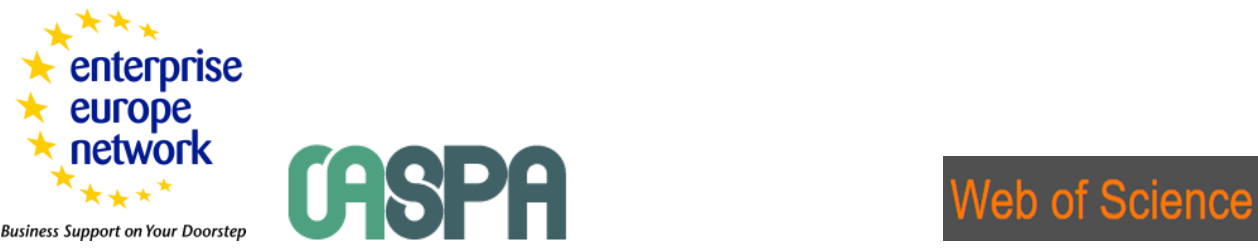

http://jssidoi.org/esc/home

1) Clarivate

Analytics

\title{
SUCCESS FROM THE PERSPECTIVE OF FEMALE ENTREPRENEURS *
}

\author{
Zsuzsanna Gódány ${ }^{1}$, Ladislav Mura ${ }^{2 *}$ \\ ${ }^{1}$ Faculty of Economics and Informatics, J. Selye University, Bratislavská cesta 3322, 945 01, Komárno, Slovakia \\ ${ }^{2}$ Faculty of Economics and Business, Pan-European University, Tematínska 10, 851 05, Bratislava, Slovakia \\ E-mails: ${ }^{1}$ godanyz@ujs.sk ; ${ }^{2}$ ladislav.mura@gmail.com (corresponding author)
}

Received 15 September 2020; accepted 22 November 2021; published 30 December 2021

\begin{abstract}
The research in the field of entrepreneurial activity is increasing. In addition to classical economic definitions, researchers are trying to capture this phenomenon in subjective terms. Some research focuses on the fact that female entrepreneurs cannot be examined purely on the basis of economic factors, since subjective factors are in many cases more important for women. Within the framework of this study, we are trying to define how female entrepreneurs in Slovakia interpret the concept of success, as well as explore the relationship between subjective and objective success factors. We used a combined research method to answer all these questions, so we conducted a questionnaire survey and in-depth interviews were applied as a qualitative part of the research. Our results confirmed the conclusions of previous research focusing on subjective, so-called non-economic goals. It has been confirmed from both quantitative and qualitative perspective that independence gives female entrepreneurs the opportunity to have free time and therefore can perform their family responsibilities more flexibly, which results in being satisfied with their private life. In addition to independence, female entrepreneurs are also proved to be satisfied if they are successful in meeting the objectives they set to achieve by the business they lead. Thus, independence and achievement of goals contribute to personal and corporate satisfaction Together with the achievement of company goals, female entrepreneurs feel successful when their business is constantly evolving. Our research analyses shows that the subjective factors we measured, the factors that do not directly contribute to the entrepreneur's internal satisfaction are economic and objective factors.
\end{abstract}

Keywords: female entrepreneurs; entrepreneurial success; subjective success factors; objective success factors

Reference to this paper should be made as follows: Godany, Z., Mura, L. 2021. Success from the perspective of female entrepreneurs. Entrepreneurship and Sustainability Issues, 9(2), 521-534. http://doi.org/10.9770/jesi.2021.9.2(34)

JEL Classifications: L25, L26, D91

\footnotetext{
* This research was supported by the project VEGA 1/0813/19, Managing the development of innovative and start-up forms of businesses in international environment and verification of INMARK concept, which has received funding from Ministry of Education, Science, Research and Sport of the Slovak Republic, and project GAAA 5-5/2020, Development of family businesses in Slovak regions, which has received funding from Grant Agency Academia aurea.
} 


\section{Introduction and theoretical background}

The research in the field of entrepreneurial activity is increasing. In addition to classical econimic definitions, researchers are trying to explain this phenomenon in subjective terms (Peráček, 2019; Milovic et al., 2020). Some research activites focus on the fact that female entrepreneurs cannot be examined purely on the basis of economic factors, since subjective factors are in many cases more important for women. There are differences in management, leadership, entrepreneurship, financial and another conditions (Smerek \& Šurinčíková, 2020; Sajfert et al., 2019; Machova \& Zsigmond, 2019; Dudić, Z. et al., 2020; Oláh et al., 2021; Mihokova et al., 2018; Konecna \& Andrejovska, 2020).

Before interpreting the concept of entrepreneurial success, it is essential to clarify the interpretations related to the term 'success'. The Hungarian interpretative dictionary provides the following definition for success: "Action, activity that results in success, completed successfully. Successful action, operation, method, propaganda or enterprise. You have successfully completed the work. He passed the exam successfully" (Arcanum, online). The English interpretative dictionary gave the following definitions for the English term "success":

- "a favourable or prosperous completion of experiments or endeavors; achieving the objectives;

- acquisition of property, situation, respect or the like;

- a performance or achievement characterised by success and the awarding of medals;

- a person or thing who has had success by achieving the goals". (Dictionary. online)

Based on the definitions presented above, success as an expression can be considered a positive result of the action/actions performed by the individual.

Entrepreneurial success is a complex phenomenon that does not have a clear definition. Researchers try to define the concept of entrepreneurial success along different variables and from different perspectives (Belas et al., 2020; Dvorsky et al., 2021; Ključnikov et al., 2019; Korcsmáros, 2018). However, they all agree that societies benefit from successful entrepreneurship, and it is important to deal with entrepreneurial success as a concept by defining which variables can be measured (Casson, 2003; Wach \& Bilan, 2021).

The intensity of research in the field of entrepreneurial success is presented in the figure below. The number of articles published in Web of Science and Scopus databases is increasing every year. As far as the field of science is concerned, most studies have been published in the field of business and management. $70 \%$ of the studies are concentrated in the WoS database in these two fields. 34.2\% of the studies are published in Scopus database, and $16.5 \%$ are represented in Scopus database. 


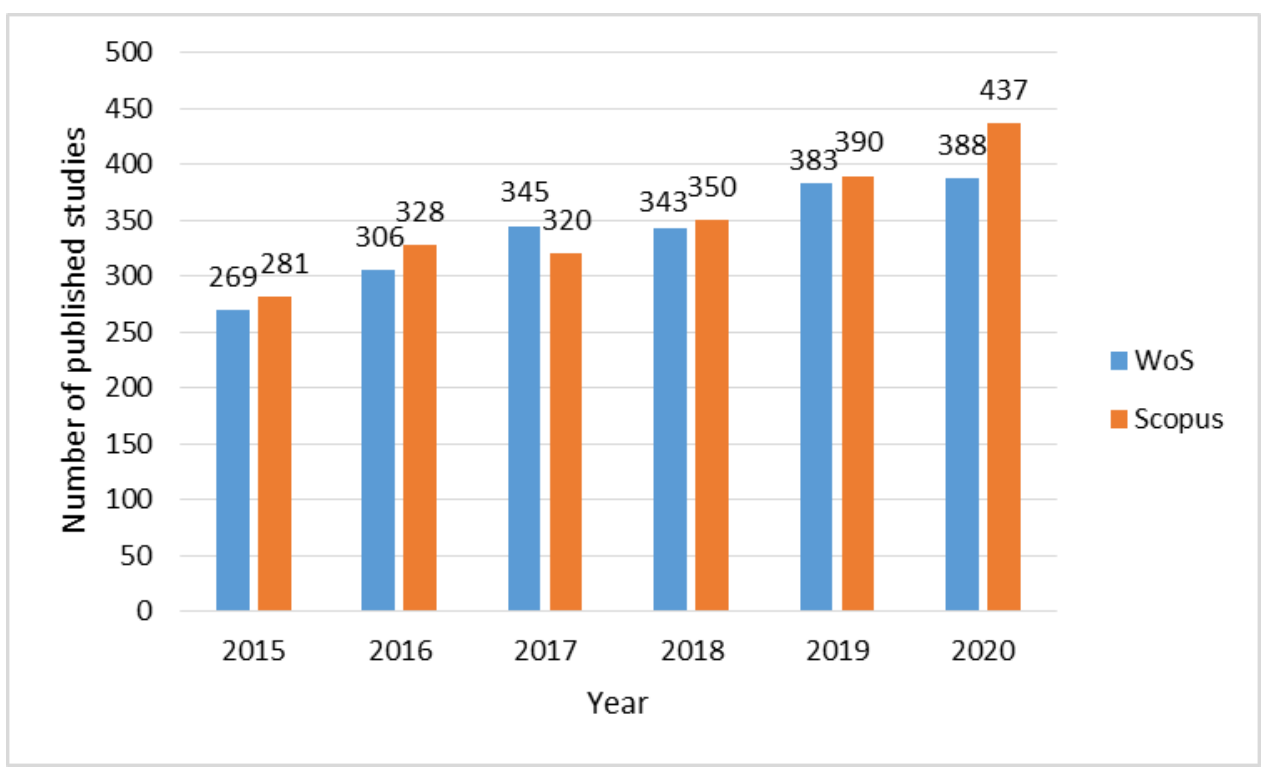

Figure 1. Evolution of the number of studies published in the database on entrepreneurial success between 2015 and 2020 Source: self-editing based on WoS and Scopus database data

When we talk about success in a business context, we mean the successful entrepreneurial activity and the success of the enterprise itself (Crane-Crane, 2007). Entrepreneurial success in research is usually a dependent variable. At the same time, it should be noted that entrepreneurial success can be temporary in terms of time.

Based on the scientific literature, entrepreneurial success can be determined on the basis of indicators, which can be widely displayed. These indicators can have economic, psychological or social nature. Entrepreneurial success can be considered as a complex phenomenon with a number of criteria in financial and non-financial terms and innovativeness (Gorgievski et al., 2010, Orser \& Dyke, 2010; Saulius et al., 2020; Hajduová et al., 2021; Ključnikov et al., 2021; Bačík \& Gburová, 2016; Pakurár et al., 2020; Zsigmond et al., 2021).

In studies about the success of female entrepreneurs, it is essential to define qualitative factors, as well as define success along subjective non-financial and objective variables. Women mostly run micro-enterprises and operate in the field that may not necessarily be a primary sector of the economy (Weber-Geneste, 2014). Entrepreneurial success cannot be assessed by a single indicator or on the basis of economic indicators. At the initial level of determining success, researchers were trying to define business success with a help of a single metric. Ettl and Welter (2012) believe that entrepreneurial success should be approached from a perspective that includes social, economic and individual aspects. In social terms, a female entrepreneur can be considered successful if her actions bring benefits to society, particularly, contributing to social responsibility regarding employees (Mishchuk et al., 2020), but at the same time she is considered to be successful if her entrepreneurial activity is closely related to her individual motivations or achievement of goals. The perception of goals achievement and used indicators of business success can differ essentially due to the conditions of business activity, determining by entrepreneurial surrounding (Paudel \& Devkota, 2018; Saidat et al., 2020).

In their study, Brush and Hisrich examined the factors determining the performance of businesses run by female entrepreneurs. According to the results, the differences in performance of male and female entrepreneurs depend on employee measurments, and emphasize that in addition to financial measures, further indicators have to be considered, which reflect the interactions between the performance, objectives and success (Brush et al, 2006). 


\section{ENTREPRENEURSHIP AND SUSTAINABILITY ISSUES}

ISSN 2345-0282 (online) http://jssidoi.org/jesi/ 2021 Volume 9 Number 2 (December)

http://doi.org/10.9770/jesi.2021.9.2(34)

The table 1 below summarises the definitions of entrepreneurial success in terms of female enterprises

Table 1. Defining entrepreneurial success in terms of female enterprises

\begin{tabular}{|l|l|}
\hline Author/Authors & Entrepreneurial success in female enterprises \\
\hline Nieman et al. (2003) & $\begin{array}{l}\text { Successful female entrepreneurs are those who do business longer than two years, } \\
\text { have more than five but less than thirty employees, make profit, and expand in terms } \\
\text { of infrastructure. }\end{array}$ \\
\hline Ettl-Welter (2012) & $\begin{array}{l}\text { Female entrepreneurs cannot be called "unsuccessful" on the basis of financial results } \\
\text { of the business. }\end{array}$ \\
\hline & Source: self-editing based on the defintions of authors
\end{tabular}

Just as entrepreneurial success itself is a complex phenomenon, therefore the attempt to measure it is not an easy process. When determining indicators, we must take into account what we would like to examine. If we look at entrepreneurial activities in order to achieve entrepreneurial success, we must take into account that entrepreneurial success may vary within certain stages of the lifecycle of the business. Success may be different for the enterprise starting its business activity, business during the period of growth and the business in its declining phase.

Another factor may be the type of the business. Social enterprises do not seek to maximise their profits, and it is therefore not appropriate to measure entrepreneurial success on the basis of financial indicators (Austin et al, 2006). It is much more important for social enterprises to achieve their goals and have an impact on their environment, including impact on local communities (Kostiukevych et al., 2020; Marišová et al., 2021).

In the fisher-maritz-lobo (2014) research, the authors identified individual and macro-level success indicators that show an important relationship between the entrepreneur and the business. This study concluded if entrepreneurs believe in their success, they achieve entrepreneurial success and perceive entrepreneurial success through individual-macro-level variables, both through personal and business performance indicators.

Table 2 summarises the indicators of the most important entrepreneurial success at personal and organizational level (Dej, 2010).

Table 2. Indicators of entrepreneurial success at individual and organisational level

\begin{tabular}{|c|c|}
\hline Personal success indicators & Organizational success indicators \\
\hline Self-realization & Survival of the company \\
\hline Independence & Number and increase of employees \\
\hline Financial security/ income & Return on investments \\
\hline Challenging, interesting tasks & Cash flow \\
\hline Being your own boss /influence & Sales and their growth \\
\hline Reputation/prestige & Market share and expansion \\
\hline Social interactions with employees and customers & Overall corporate performance and growth \\
\hline Requested service, provision of products & achieve better results than competitors \\
\hline
\end{tabular}

Source: Dej, 2010

\section{Research objective and methodology}

In our research, we addressed the following questions: How do female entrepreneurs think about success? Are subjective factors more important than objective ones? Are both factors equally important? The research has a focus to examine the relationship between the subjective and objective success factors.

It focused on female entrepreneurs who have a registered business in Slovakia. It was considered important that individuals who actually run/manage the company should be included in the sample and not merely as 'silent 


\section{ENTREPRENEURSHIP AND SUSTAINABILITY ISSUES}

ISSN 2345-0282 (online) http://jssidoi.org/jesi/ 2021 Volume 9 Number 2 (December)

http://doi.org/10.9770/jesi.2021.9.2(34)

partners'. Based on these criteria, the target area has been defined as female entrepreneurs as sole owners or coowners of the business.

Questionnaire survey was applied as a quantitative technique. We found it the most appropriate method to collect quantitative data and perform statistical analysis. A semi-structured interview was applied as a qualitative research method.

Entrepreneurial success was measured on the basis of objective and subjective factors. Subjective success has been captured along personal, entrepreneurial and social dimensions. Our latter variables have been determined on the basis of previous research (Fisher-Maritz-Lobo, 2014) (Arasti - Zandi - Talebi, 2012). The following table 3 summarizes the variables used to measure success. Some variables of subjective success were measured on a 6point Likert scale.

Table 3. Summary table of success variables

\begin{tabular}{|l|l|l|}
\hline \multicolumn{2}{|c|}{ Objective success variables } & $\begin{array}{l}\text { Measurement } \\
\text { level }\end{array}$ \\
\hline Variable Name & Measurement of variables & ordinal scale \\
\hline Age of enterprise & Age of enterprise & ordinal scale \\
\hline Number of employees & Number of employees & \multicolumn{1}{|c|}{ Subjective success variables } \\
\hline \multicolumn{2}{|c|}{ Measurement } \\
\hline Variable Name & Measurement level & ordinal scale \\
\hline Personal success1 & Satisfaction with private life and business & ordinal scale \\
\hline Personal success2 & Feeling free to work & ordinal scale \\
\hline Personal success3 & Exceeding the objectives set at the time of setting up the business & ordinal scale \\
\hline Business success1 & Developing your business & ordinal scale \\
\hline Business success 2 & Providing quality product/service - satisfied customers, customers & ordinal scale \\
\hline Financial success1 & Company turnover in the period of 2015-2019 & ordinal scale \\
\hline Social success1 & Support for local entrepreneurs, organisations and individuals & \\
\hline
\end{tabular}

Source: own processing

The questionnaire data collection took place two months. A total of 271 questionnaires were filled in by the respondents, while 1 questionnaire was excluded from the evaluation, as it was completed by a male respondent. In the case of qualitative research, it was an important aspect to create a sample represented by different profiles of companies and different age groups of entrepreneurs. We wanted to involve both young and experienced entrepreneurs. The book "49 hrdiniek slovenského biznisu", which presents 49 female entrepreneurs from Slovakia, provided a base for selection of interview subjects. We managed to interview 3 female entrepreneurs and 13 more were addressed. Each interview took 30-40 minutes. We used the SPSS quantitative data analysis software and the NVivo qualitative data analysis tool to process the obtained data.

\section{Results and discussion}

Defining the concept of success and measuring success is a complex task. Our research focus is greatly influenced by the definition of authors on success presented earlier in this work. When mapping the success of female entrepreneurs, we did not want to evaluate them only on the basis of company performance data, as female entrepreneurs have diverse approach to success. We wanted to know what success means to individual entrepreneurs, as well as examine this phenomenon on the basis of the subjective factors we define. 


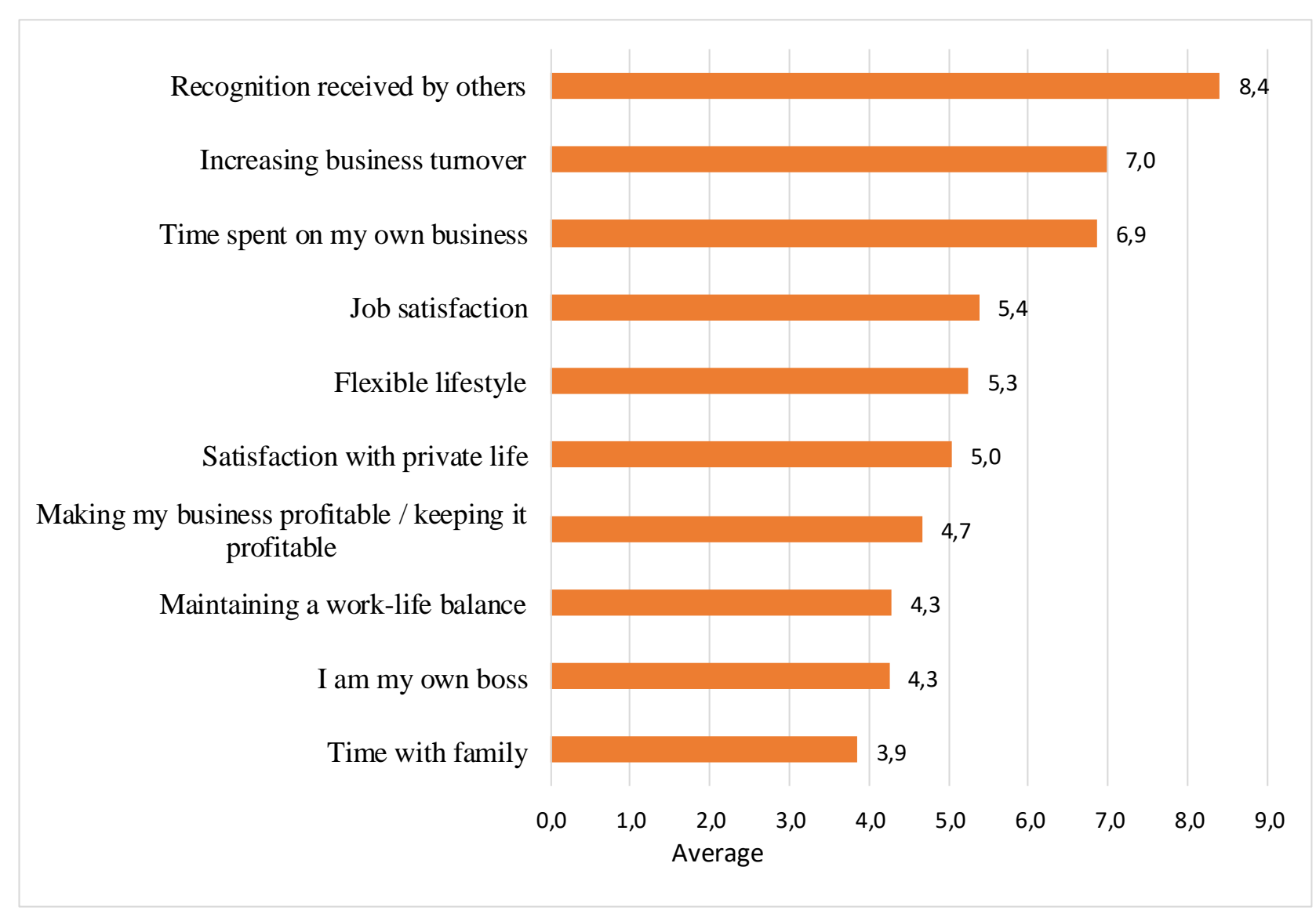

Figure 2. Average preference values of the respondents

Source: own primary research and calculation

The success of businesses is often measured via financial indicators, but some previous studies have shown that female entrepreneurs do not necessarily consider the profitability of the business and the increase of turnover to be the primary concern. Our questionnaire asked the female interviewees to rank those 10 factors we have listed based on the importance. The most important factor came first. The figure below shows the average values calculated for each preference based on the aggregated data of the respondents. Based on the values, we can see that the most important for the sampled respondents is to spend time with their family, maintain healthy work-life balance and manage their own time to define their tasks. Making the company profitable is ranked 4th in terms of average values, and increasing the turnover of the enterprise is in 9th place. The last is the recognition received from others. It means that recognition at social level is not important for the female entrepreneurs involved in the survey. At the same time, it is important to note that the opinion of the respondents on this issue is not uniform, since the value of the standard deviation is high for all factors.

In addition to individual preferences, success has been measured along 6 additional variables, the aggregate results of which are illustrated in the table below. The research made difference between thinking about success and feeling successful, so we measured both phenomena along 6-6 variables. The respondents were provided a 6point scale to express in what extent they agree with the provided statement. The lowest value on a scale 1expressed the absolute disagreement with the statement, while 6 means absolutely agree. 
Table 4. Thinking about success and feeling successful

\begin{tabular}{|c|c|c|c|}
\hline Factors & $\begin{array}{c}\text { Thinking about success - } \\
\text { average value }\end{array}$ & $\begin{array}{l}\text { Sense of success in the } \\
\text { present - average value }\end{array}$ & IDEAL value \\
\hline $\begin{array}{l}\text { If I am happy with my personal life and } \\
\text { business. }\end{array}$ & 5,28 & 5,13 & 6 \\
\hline $\begin{array}{l}\text { If I can do what I love in my life and } \\
\text { business. }\end{array}$ & 5,44 & 5,28 & 6 \\
\hline If my business is constantly evolving. & 5,35 & 5,13 & 6 \\
\hline $\begin{array}{l}\text { If I managed to go beyond the goals I set } \\
\text { when I started the business. }\end{array}$ & 5,01 & 4,90 & 6 \\
\hline If my customers / clients are satisfied. & 5,63 & 5,53 & 6 \\
\hline If I create a job for the local community. & 4,02 & 3,73 & 6 \\
\hline \multicolumn{4}{|c|}{ Estimate } \\
\hline Factors & $\begin{array}{c}\text { The combined value of a sense of } \\
\text { success and thinking about } \\
\text { success }\end{array}$ & $\begin{array}{c}\text { Thinking about success - ideal } \\
\text { value }\end{array}$ & Difference \\
\hline $\begin{array}{l}\text { If I am happy with my personal life and } \\
\text { business. }\end{array}$ & 27,1 & 31,7 & 5 \\
\hline $\begin{array}{l}\text { If I can do what I love in my life and } \\
\text { business. }\end{array}$ & 28,7 & 32,6 & 4 \\
\hline If my business is constantly evolving. & 27,4 & 32,1 & 5 \\
\hline $\begin{array}{l}\text { If I managed to go beyond the goals I set } \\
\text { when I started the business. }\end{array}$ & 24,5 & 30,1 & 6 \\
\hline If my customers / clients are satisfied. & 31,1 & 33,8 & 3 \\
\hline If I create a job for the local community. & 15,0 & 24,1 & 9 \\
\hline
\end{tabular}

Source: primary research and calculation 
We believe that thinking about success and feeling successful should not be treated separately, but should be analysed jointly. Thus, we determined the combined value of the experience of success and thinking about success. We also calculated the ideal value of thinking about success, which we obtained by multiplying thinking about success by ideal value. The "difference column" in the table 4 shows the extent to which the combined value of thinking and feeling about success differs from the ideal value of thinking about success.

Based on the table, we can say that the average values of thinking about success and the feelings associated with success move together. The most important for those surveyed is the customer in general, the satisfied customer, and the entrepreneurial freedom. The latter factor was ranked prominently in the ranking of previous preferences in relation to the variable I am the "master" of myself.

When examining success, we wanted to find out the relationship between the different success variables. We were interested in the relationship between objective and subjective variables. In order to answer this question, we performed a correlation calculation and applied the Spearman rank correlation.

Positive significant relationship was found between the subjective factors (indicated with orange in Figure 3). In addition to positive relationship, we found a strong connection between private life, business satisfaction and between what I want to do in my life $(r s=0.651 ; p<0.01)$ and overperforming the goals $(r s=0.633 ; p<0.01)$. The following variable pairs were characterized by a medium relationship:

- private life and business satisfaction - my business is constantly evolving ( $r s=0.465 ; \mathrm{p}<0.01)$;

- I can do what I want in my life and business - my business is constantly evolving ( $r s=0.524 ; \mathrm{p}<0.01$ ); exceeding targets $(\mathrm{rs}=0.579 ; \mathrm{p}<0.01)$; satisfied with my customers ( $\mathrm{rs}=0.408 ; \mathrm{p}<0.01)$.

We found a weak positive relationship between job creation and other subjective success factors. We also examined the relationship between objective economic and subjective non-economic factors and subjective economic factors. 


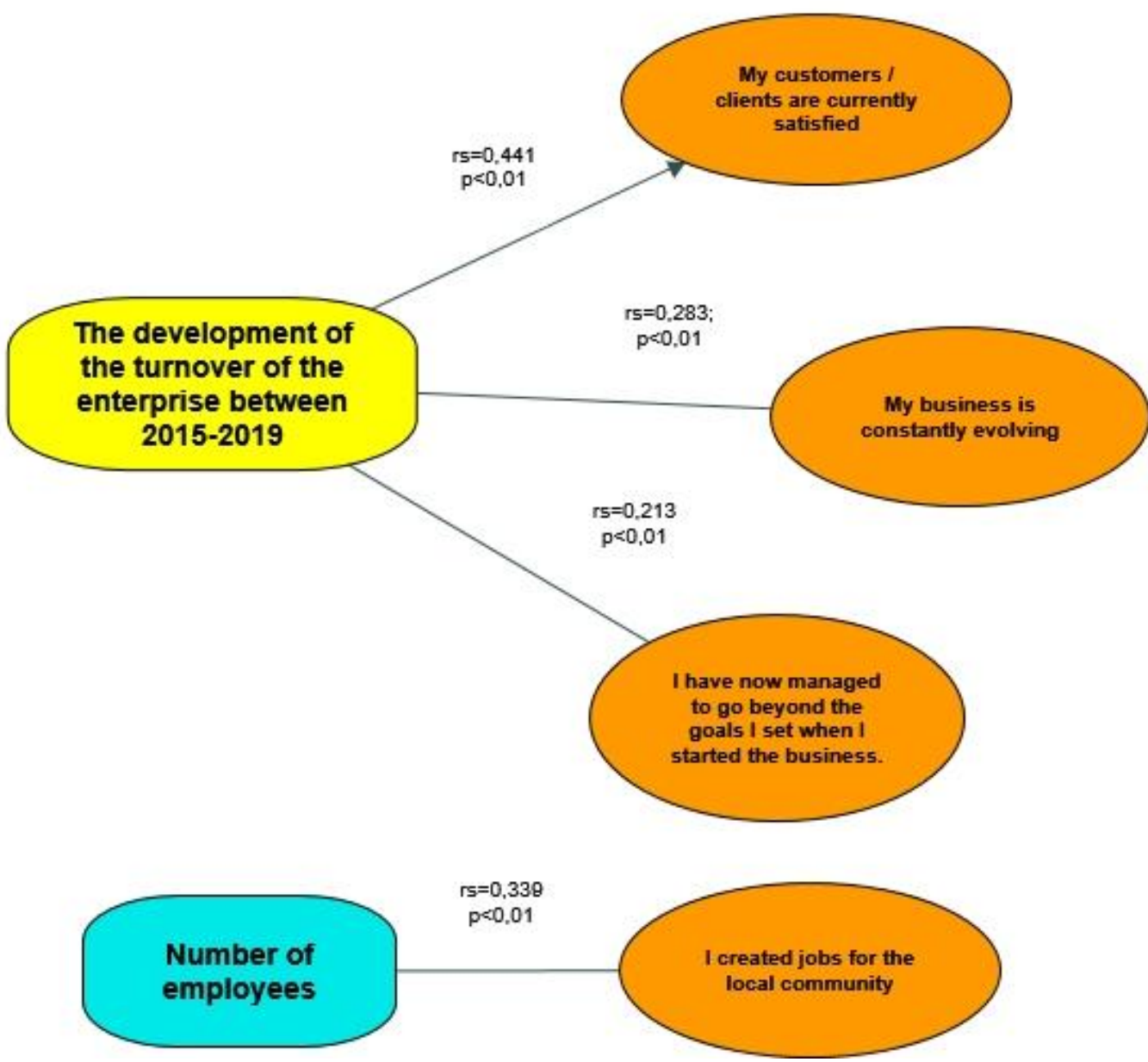

Figure 3. Relationship between subjective and objective success factors Source: own processing based on own research

In the case of objective factors, no significant relationship was found with regard to the age of the enterprise, neither with subjective variables, nor with a variable called the age of the objective enterprise. We identified a positive medium relationship between the number of employees and the subjective variable for job creation, and it was the subjective economic factor that most correlated with other non-economic subjective success factors. The figure shows that there is a weak or medium positive relationship between our variables. We can also observe that the subjective economic factor correlates with subjective non-economic factors that are not specifically related to the entrepreneur, but to the enterprise itself.

In our questionnaire survey, the interviewees were asked an open question about what success means to them. The results were processed on the basis of Dej (2010) research. Dej (2010) examined the personal and organizational success in terms of different factors. First of all, let's look at the answers of the interviewees based on factors related to personal success. 


\section{ENTREPRENEURSHIP AND SUSTAINABILITY ISSUES}

ISSN 2345-0282 (online) http://jssidoi.org/jesi/

2021 Volume 9 Number 2 (December)

http://doi.org/10.9770/jesi.2021.9.2(34)

- Self-realisation - Definitions related to self-realisation amounted for $24 \%$ of the answers. In some cases, respondents used the term self-realization specifically when it came to defining success. According to one of the respondents: 'Self-realisation leads to personal satisfaction'; "Success is, when I feel happy with my life". At the same time, the joy of work, satisfaction with work, satisfaction with private life and satisfaction with themselves also appeared.

- Independence - As a synonym for this success factor, we have often used the terms 'freedom' and 'opportunity'. One of the respondent expressed the feeling of freedom of choice as the following: "Being free to decide about my daily tasks". The respondent does not experience work as a cumpolsory activity, but experiences joy from her work on emotional level. "A man who never knows when Monday is, can be declared successful - that person feels happy to start the week". The respondent does not feel about her work as a necessary activity to survive, but as an activity she likes to spend time with and enjoys her work.

- Financial security/ income - definitions related to achieve financial security accounted for $14 \%$ of the responses, which is the 3rd highest percentage among factors. The term stability was often used by the respondents in relation to this factor, but the respondents also listed financial security and good financial situation to provide comfortable life or become self-sufficient. Finances were also mentioned in relation to the well-being of the family, as it is indicated in the following sentence: "I would like to ensure an a descent life for my family”. Some of the respondents provided an answer ,do not have to work”, which was interpreted as the respondent has already reached the desired financial stability and would like to devote less time and energy to work.

- Challenging and interesting tasks - This factor was not interpreted as fulfillment of challenging tasks, but achieving the goals previously set.

- Being your own boss /influence - I am the "master" of myself, as one respondent wrote. It is important to highlight the importance of time management and work-life balance. Work-life balance was important for most of the respondents as it is summarized by the respondent: "Interpretation of success is different for all of us. „My personal interpretation of success is achieving a healthy work-life balance."

- Reputation/Prestige - in particular, we must mention achieving good reputation in the market, positive reputation of the company, recognition by competitors and the need for presence on the market.

- Social interactions with employees and customers - $22 \%$ of the responses concentrated on this issue. Satisfied customers, positive customer feedback and satisfied employees were also included in the list.

- Providing the requested service/product - Some of the respondents think that being able to provide a service useful for the society is a positive thing in terms of success.

When analysing the respondents' responses, we found that these factors do not exist in isolation, but merged into one - several factors in a single response. Another group of success factors is formed by factors related to the organization. We will list only those we were able deduct based on the respondent's opinion. We would like to highlight 3 factors:

- $\quad$ survival of the company -"It is a success for me that the company is 20 years old, operating in a business sector that is slowly disappearing." - the answer was provided by a baker, who is able to maintain his business even in difficult conditions, which requires hard work. Even continuity plays a role in this factor, i.e. continuous operation.

- Number of employees / increase the number of employees - "Success is that I can provide work and income to other people." As the sample is mainly represented by micro-enterprises, employing people considered to be a success factor for these type of businesses.

- business performance and growth - this factor was indicated by the respondents who think about success in terms of profit maximization, corporate growth, business development, high revenues and profitability. 


\section{ENTREPRENEURSHIP AND SUSTAINABILITY ISSUES}

ISSN 2345-0282 (online) http://jssidoi.org/jesi/

2021 Volume 9 Number 2 (December)

http://doi.org/10.9770/jesi.2021.9.2(34)

When analyzing the answers, we were interested in the ratio between personal and organizational success factors. Personal factors are more emphasized by the respondents, only 6 percent of the responses were directly related to the success factors of the organization.

In our interviews, we asked the entrepreneurs what success means to them. Responses are coded based on personnel and organizational factors. In relation to personal success, the most frequent responses were „satisfied”, „positive feedback” and „satisfaction by achieving the desired goal”. In terms of organizationa success, the respondents used the following expressions: "long-term operation", "increasing sales" and "company development". The results obtained as a result of interviews showed that the personal success factors are emphasized. 11 out of 16 interviewees said that they defined success based on their own personal factors. The remaining 5 respondents described success as a term based on both personal and organizational success factors.

\section{Conclusion}

The scientific literature and research related to entrepreneurial success defines success in terms of economic performance. Female entrepreneurial activity is not a widely discussed issue and is rarely addressed in the scientific literature focusing on business performance. At the same time, there are examples, where women tend to focus on non-economic factors when assessing their business activity. These non-economic factors include personal fulfilment, the pursuit of flexibility, customer satisfaction and personal satisfaction.

This research addressed to measure the success of female entrepreneurs on the basis of both economic and noneconomic indicators. Our results confirmed the conclusions of previous research focusing on subjective, so-called non-economic goals.

When defining success in both quantitative and qualitative terms, it was confirmed that providing workplace independence in the case of female entrepreneurs provides them an opportunity to create a healthy work-life balance, perform family responsibilites more flexibly, thus making them feel satisfied with their family life. In addition to workplace freedom, achieving corporate goals will make these entrepreneurs satisfied, as well as the development of their business.

Among the subjective non-economic success factors, job creation was the only variable that was undervalued by the female entrepreneurs compared to other factors. We came to conclusion that this is a basic success factor for female entrepreneurs with employees. It does not necessarily mean that this socially important factor is negligible for female entrepreneurs, but shows that the number of female entrepreneurs who do not have or have maximum 1 employee is high in the sample. In terms of objective factors we detected a weak relationship between the age of the company existence and the number of employees, while there is a relaptionship between the number of employees and job creation. The entrepreneurs who feel more successful in terms of customer/customer satisfaction, have increased their turnover in 2015-2019. Based on the analysis we can summarize that the subjective factors measured by us do not directly contribute to the entrepreneur's satisfaction. 


\section{ENTREPRENEURSHIP AND SUSTAINABILITY ISSUES}

ISSN 2345-0282 (online) http://jssidoi.org/jesi/

2021 Volume 9 Number 2 (December)

http://doi.org/10.9770/jesi.2021.9.2(34)

\section{References}

Arasti, Z., Zandi, F., \& Talebi, K. (2012). Exploring the Effect of Individual Factors on Business Failure in Iranian New Established Small Businesses. International Business Research, 5(4), 2-11. https://doi.org/10.5539/1br.v5n4p2

Austin, J., Stevenson, H., \& Wei-Skillern, J. (2006). Social and Commercial Entrepreneurship: Same, Different, or Both? Entrepreneurship Theory and Practice, 30(1), 1-22. https://doi.org/10.1111/j.1540-6520.2006.00107.x

Bačík, R., \& Gburová, J. (2016). Internet and its influence on the consumer behavior of Slovak consumer. Proceedings of the 28th International Business Information Management Association Conference - Vision 2020: Innovation Management, Development Sustainability, and Competitive Economic Growth, $3342-3347$

Belas, J., Cepel, M., Kliuchnikava, Y., \& Vrbka, J. (2020). Market risk in the SMEs segment in the Visegrad group countries. Transformations in Business and Economics, 19(3), 678-693

Brush, C. G. et al. (2006). Growth-oriented Women Entrepreneurs and their Businesses. Edward Elgar Publishing Limited, 432 p.

Casson M. (2003). Entrepreneurship, Business Culture and the Theory of the Firm. In: Acs Z.J., Audretsch D.B. (eds) Handbook of Entrepreneurship Research. International Handbook Series on Entrepreneurship, vol 1. Springer, Boston, MA. https://doi.org/10.1007/0-387-24519-7_10

Crane G.F., \& Crane E.C. (2007). Dispositional Optimism and Entrepreneurial Success. The Psychologist-Manager Journal, 10(1), 13-25. https://doi.org/10.1080/10887150709336610

Dej, D. (2010). Defining and measuring entrepreneurial success. Entrepreneurship: A Psychological Approach. Prague: Oeconomica, 89-102.

Dudić, Z., Dudić, B., Agbaba, B, \& Nosková, M. (2020). The importance and application of the balanced scorecard model in enterprises. Acta Oeconomica Universitatis Selye, 9(1), 45-56

Dvorsky, J., Belas, J., Gavurova, B., \& Brabenec, T. (2021). Business risk management in the context of small and medium-sized enterprises. Economic Research-Ekonomska Istrazivanja, 34(1), 1690-1708

Ettl K., \& Welter F. (2012). Women Entrepreneurs and Success. In: Galindo M.A., Ribeiro D. (eds) Women's Entrepreneurship and Economics. International Studies in Entrepreneurship, vol 1000. Springer, New York, NY. https://doi.org/10.1007/978-1-4614-1293-9 6

Fisher, R., Maritz, A., \& Lobo, A. (2014). Evaluating entrepreneurs' perception of success: Development of a measurement scale. International Journal of Entrepreneurial Behavior \& Research, 20(5), 478-492. https://doi.org/10.1108/IJEBR-10-2013-0157

Gorgievski, M. J., Ascalon, M. E., \& Stephan, U. (2011). Small Business Owners' Success Criteria, a Values Approach to Personal Differences. Journal of Small Business Management, 49(2), 207-232. https://doi.org/10.1111/j.1540-627X.2011.00322.x

Hajduová, Z., Peráček, T., Coroničová Hurajová, J., Brouthová, M. (2021). Determinants of innovativeness of Slovak SMEs. Problems and Perspectives in Management, 19(1), 198-208. https://doi.org/10.21511/ppm.19(1).2021.17

Ključnikov, A., Civelek, M., Fialova, V., \& Folvarčná, A. (2021). Organizational, local, and global innovativeness of family-owned SMEs depending on firm-individual level characteristics: evidence from the Czech Republic. Equilibrium. Quarterly Journal of Economics and Economic Policy, 16(1), 169184. https://doi.org/10.24136/eq.2021.006

Ključnikov, A., Civelek, M., Čech, P., \& Kloudová, J. (2019). Entrepreneurial orientation of SMEs? Executives in the comparative perspective for Czechia and Turkey. Oeconomia Copernicana, 10(4), 773-795. https://doi.org/10.24136/oc.2019.035

Konecna, V., \& Andrejovska, A. (2020). Investor decision-making in the context of the effective corporate taxation. E \& M Ekonomie a Management, 23(1), 111-120. https://doi.org/10.15240/tul/001/2020-1-008

Korcsmáros, E. (2018). Factors affecting the development of SMEs (example from Slovakia based on primary research in Nitra region). Acta Oeconomica Universitatis Selye 7(1), 70-78

Kostiukevych, R., Bilan, Y., Mishchuk, H., Sułkowska, J. \& Kostiukevych, A. (2020). Possibilities of Integration of Strategic and Project Management in The Supporting System of Small and Medium-Sized Businesses at Local and Regional Levels. Proceedings of the 35th International Business Information Management Association (IBIMA), 9253-9265.

Machova, R., Zsigmond, T. (2019). Generational differences in terms of labour market and mobile applications. International Scientific Conference on the Impact of Industry 4.0 on Job Creation, 136-144

Marišová E., Lichnerová, I., \& Machyniak, J. (2021). Efficiency of the functioning of public administration: regional empirical study. Administratie si Management Public, 36, 165-180. https://doi.org/10.24818/amp/2021.36-10 


\section{ENTREPRENEURSHIP AND SUSTAINABILITY ISSUES}

ISSN 2345-0282 (online) http://jssidoi.org/jesi/

2021 Volume 9 Number 2 (December)

http://doi.org/10.9770/jesi.2021.9.2(34)

Mihokova, L., Andrejovska, A., \& Martinkova, S. (2018). Tax Competitiveness of EU Member States in the Context of Corporate Taxation. Politicka Ekonomie, 66(5), 588-608. https://doi.org/10.18267/j.polek.1206

Milovic, N., Jocovic, M., \& Djurisic, V. (2020). The Role of Entrepreneurship in the Development of Local Self-Governments in Montenegro. Transformations in Business \& Economics, 19, 2(50), 159-170.

Mishchuk, H., Bilan, S., Yurchyk, H. \& Sułkowska, J. (2020). Social Protection of Employees as a Tool of Social Responsibility and Increase of Business Efficiency Proceedings of the 35th International Business Information Management Association (IBIMA), 9459-9469.

Nieman, G., Hough, J., \& Nieuwenhuizen, C. (2003). Entrepreneurship: A South African perspective. Pretoria: Van Schaik.

Oláh, J., Hidayat, Y. A., Dacko-Pikiewicz, Z., Hasan, M., \& Popp, J. (2021). Inter-Organizational Trust on Financial Performance: Proposing Innovation as a Mediating Variable to Sustain in a Disruptive Era. Sustainability, 13(17), 9947, 1-19. https://doi.org/10.3390/su13179947

Orser, B., \& Dyke, L. (2009). The Influence of Gender and Occupational-Role on Entrepreneurs' and Corporate Managers' Success Criteria. Journal of Small Business and Entrepreneurship, 22(3), 327-353. https://doi.org/10.1080/08276331.2009.10593459

Paudel, U.R., \& Devkota, N. (2018). Socio-economic influences on small business performance in Nepal-India open border: Evidence from crosssectional analysis. Economics and Sociology, 11(4), 11-30. https://doi.org/10.14254/2071- 789X.2018/11-4/1

Pakurár, M., Khan, M.A., Benedek, A., \& Oláh, J. (2020). The impact of green practices, cooperation and innovation on the performance of supply chains using statistical method of meta-analysis. Journal of International Studies, 13(3), 111-128. https://doi.org/10.14254/2071-8330.2020/13-3/8

Peráček, T. (2019). Why is a simple company on shares an unnecessary type of business? Proceedings of the 33rd International Business Information Management Association Conference, IBIMA 2019: Education Excellence and Innovation Management through Vision 2020, $3282-3290$

Saidat, Z., Bani-Khalid, T., Al-Haddad, L., \& Marashdeh, Z. (2020). Does family CEO enhance corporate performance? The case of Jordan. Economics and Sociology, 13(2), 43-52. https://doi.org/10.14254/2071-789X.2020/13-2/3

Sajfert, D., Nikolič, M., Vukonjanski, J., Terek, E., \& Vulovič, M. (2019). The impact of ethical leadership behavior on communication satisfaction and organizational learning in companies in Serbia. Acta Oeconomica Universitatis Selye, 8(1), 138-159

Saulius, T., Valanciene, D., \& Bilan, S. (2020). Critical Thinking in Contemporary Business Education: Philosophical Perspectives. Transformations in Business \& Economics, 19, 2 (50), 21-37

Smerek, L., \& Šurinčíková, M. (2020). Perception of leadership in Slovakia. Acta Oeconomica Universitatis Selye, 9 (2), 93-105. https://doi.org/10.36007/Acta.2020.9.2.7

Wach, K., \& Bilan, S. (2021). Public support and administration barriers towards entrepreneurial intentions of students in Poland. Administratie si Management Public, 36, 67-80. https://doi.org/10.24818/amp/2021.36-04

Weber, P.Ch., \& Geneste, L. (2014). Exploring gender-related perceptions of SME success. International Journal of Gender and Entrepreneurship, 6(1), 1527. https://doi.org/10.1108/IJGE-04-2013-0038

Zsigmond, T., Machová, R., \& Zsigmondová, A. (2021). Strategic management from the perspective of SMEs operating in service sector. Quality Innovation Prosperity, 25(2), 37-53. https://doi.org/10.12776/qip.v25i2.1549

\section{Acknowledgements}

This research was supported by the project VEGA 1/0813/19 Managing the development of innovative and start-up forms of businesses in international environment and verification of INMARK concept, which has received funding from Ministry of Education, Science, Research and Sport of the Slovak Republic and project GAAA 5-5/2020 Development of family businesses in Slovak regions, which has received funding from Grant Agency Academia aurea, VEGA 1/0240/20. 


\section{ENTREPRENEURSHIP AND SUSTAINABILITY ISSUES}

ISSN 2345-0282 (online) http://jssidoi.org/jesi/

2021 Volume 9 Number 2 (December)

http://doi.org/10.9770/jesi.2021.9.2(34)

Zsuzsanna GÓDÁNY is an Assistant Professor in the Department of Management Faculty of Economics and Informatics at the J. Selye University. Research interests: SMEs, Research, Female entrepreneurs, Strategy

ORCID ID: https://orcid.org/0000-0002-2391-1638

Ladislav MURA is an Associate Professor, a Slovak expert on small and medium business, international business, and the human resource of management. He is the author of 3 domestic scientific monographs on the internationalization of business, small and medium enterprises, human resource management, co-author of foreign scientific monographs. He has published a lot of articles in various scientific journals.

ORCID ID: $\underline{\text { https://orcid.org/0000-0002-2453-8740 }}$

Make your research more visible, join the Twitter account of ENTREPRENEURSHIP AND SUSTAINABILITY ISSUES: @Entrepr69728810

Copyright (C) 2021 by author(s) and VsI Entrepreneurship and Sustainability Center

This work is licensed under the Creative Commons Attribution International License (CC BY).

http://creativecommons.org/licenses/by/4.0/

c. (i) Open Access 